INDEPENDENT JOURNAL OF MANAGEMENT \& PRODUCTION (IJM\&P)

http://www.ijmp.jor.br

v. $11, n$. 7, November - December 2020

ISSN: 2236-269X

DOI: 10.14807/ijmp.v11i7.1087

\title{
EVALUATION OF COSTS AND REWORKS IN THE TIRES RECOVERY PROCESS BY THE MONTE CARLO METHOD: CASE STUDY
}

Fernando Ailton Castellani de Oliveira Universidade Federal Fluminense, Brazil E-mail: fernando-castellani@hotmail.com

Nilson Brandalise Universidade Federal Fluminense, Brazil E-mail:nilson_01@yahoo.com.br

Submission: 6/26/2019

Revision: 9/18/2019

Accept: 10/28/2019

\section{ABSTRACT}

Companies are increasingly seeking methods to eliminate costs, and one of the big problems in companies is rework. The objective of this study was to identify costs and rework through the application of quality tools, allied to the Monte Carlo method (MMC), comprising the productive process of tire retreading, through an exploratory study. The applied methodology was in a tire retreading industry, located in the southern Fluminense region, in the state of Rio de Janeiro. One can conclude from the use of quality tools that the main failures within the process were the vulcanization, bonding and scarification / repair and also analyze by the Monte Carlo method the costs presented in the tire reform process through 5000 interactions. Through the tools, we can quantify the failures occurred in each stage. The main contribution of this work is the identification of the costs caused by the rework in the tires of automobiles and of load.

Keywords: Costs, Reworks, Monte Carlo 
DOI: 10.14807/ijmp.v11i7.1087

\section{INTRODUCTION}

According to ABR (Brazilian Association of Tire Reform Segment), 2017 over the years, the economy has been transforming and causing entities to rethink their behavior in the face of this evolution, and thus there was a need to review the plans, improve information management in order to make them clear and objective, in relation to the cost of production, general expenses of the company and also better decision making.

As a result of these transformations, there was a need to obtain updated studies regarding costs and rework, and with this, quality tools were used in order to provide better costs in the production process of a tire retreader located in Sul Fluminense, in the interior of Rio de Janeiro.

The general objective of this work is to identify the costs and rework of a tire retreader company by means of quality tools, and the following specific objectives are a) Evaluate the costs with the help of the Monte Carlo method in the process of retreading tires; b) Analyze the rework resulting from the process; c) Identify problems arising in the process through quality tools.

Within the study, we raised the following question: "How can we minimize costs and rework, with the help of quality tools and with the use of the Monte Carlo Method, showing the production values within the market of tire retreading?".

The justifications for the elaboration of this article have as analyze, through an exploratory study the relevance of the quality tools of a current market that becomes increasingly difficult, competitive and with customers increasingly demanding with the quality of products and services, companies seek techniques that aim at continuous improvements in their processes, consequently analyzing the costs and avoiding the rework arising in the process of retreading tires.

However, to carry out the development of this article, it was structured into 7 sections, starting with the introduction, following for the theoretical foundation of the topics addressed in the research: tires, tire retreading, costs, rework, quality tools and case studies. Subsequently it is argued about the methodology applied; in the following section, data collection, data analysis and finally, the conclusions and theoretical references.

\section{THEORETICAL REFERENCE}

\subsection{Tires}


DOI: 10.14807/ijmp.v11i7.1087

According to ABR (2017), the tire is an essential component in the operation of vehicles, originated in the nineteenth century with experiments initiated by Charles Goodyear, around 1830, discovered that rubber cooked at high temperatures with sulfur, remained its elastic characteristics in cold or heat. From then on, the rubber vulcanization process was discovered, which, in addition to shaping the tire, increased braking safety and also reduced shaking in cars.

Years later, in 1845, the Michelin brothers were the first to patent the automobile tire, later in 1847, the Englishman Robert Thompson, placed a chamber full of air inside the solid rubber tires and patented, thus originating the pneumatic tire. In 1888, the first bicycle tire was manufactured, and the same year it began.

The growth in manufacturing came between 1938 and 1941, with the entry of other major manufacturers who began to produce on Brazilian soil, raising production to 331,000 units, which by the end of the 80s, Brazil had already produced more than 29 million tires. Since then, Brazil has had more than 15 tire factories, four of which are international: Bridgestone, Firestone, Goodyear, Pirelli and Michelin.

The combination of raw materials, such as natural rubber, petroleum products, steel and chemical products, originates the tire. The proportion of each element varies according to what will be given to the final product, be it a truck tyre or a touring tyre. According to SINPEC (National Syndicate of the Pneumatic, Chamber of Air and Camelback Industry), in the ride tires the rubber predominates, being 27\% synthetic and 14\% natural. Carbon black constitutes $28 \%$ of the composition. Petroleum derivatives and chemical products account for $17 \%$, metallic material (or steel) for $10 \%$ and textile for $4 \%$.

Data released by ANIP (National Agency of the Tire Industry) in 2010, show that in our country there is an estimate that approximately 60 million tires are produced per year. Even if the tire lasts about seven years, it will become unusable regarding the mobility of transportation and the large volume of products discarded in inappropriate places, this generates a worrying problem for the environment.

\section{2. $\quad$ Retread tyres}

The growth of the tire manufacturing industry, caused a careful look at the waste that tires could generate with their finished useful life, so there is a financial opportunity to use retreaded tires and also the need to have companies in the industry. 
DOI: 10.14807/ijmp.v11i7.1087

Although the global rubber industry is small compared to others, tyres are a significant part of international and domestic trade (VALERIE; SHULMAN, 2019). Brazil is the second largest tire-reforming country in the world, losing only to the United States, according to the Brazilian Association of the Tyre-reforming Segment (ABR, 2017).

According to ANIP data (2017), in the transport sector, those who use this service reduce the cost $/ \mathrm{km}$ by $57 \%$. This is because, if we compare with a new tire, they pay $73 \%$ less and reform, on average, twice each tire.

It is worth mentioning that tire recycling brings several benefits for the economy, such as cost reduction, job creation and promotion of the economy with tax generation, can be considered one of the important segments in the Brazilian economy.

The sector of refurbishment in Brazil in the period between 2010 and 2015 brought a convincing growth, approximately 40\%, and reached the mark of nine million units of refurbished tires and with a recapability index (quantity of refurbished tires by that of new tires) of 1.8 .

According to Shulman (2011), it is argued:

[...] the starting point for tyre recycling is the same as in other industries - the provision of a continuous flow of raw materials. Historically, post-consumer tires have been collected separately and the classified into two sectors - the market for used (second-hand) parts and refurbishment. (p.297).

The stages of tyre retreading are in accordance with figure 1, pointing out that in these stages the tyre is suitable for retreading.

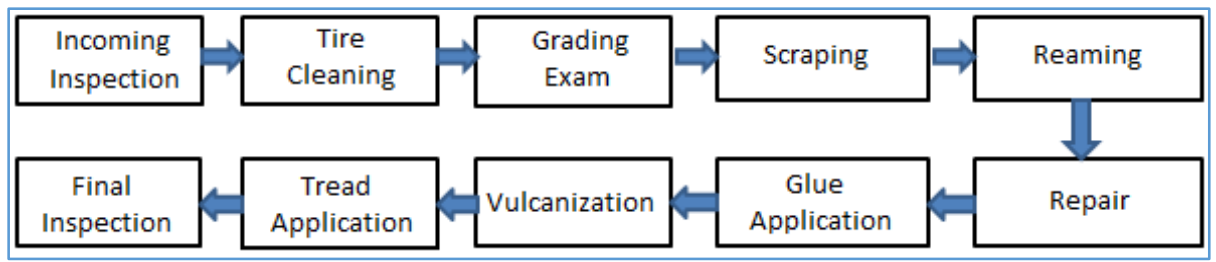

Figure 1: Retreading process of the tyre Source: prepared by the authors (2019)

Reuse, recycle and reduce are the main words that we must think through actions to reduce the environmental impacts that have been growing visibly, both in the generation of resources and also in their consumption. In Brazil, it is estimated that 70 million tires are produced annually, at least 450 thousand tons of tires, that is to say, 90 million units used in automobiles (ANIP, 2017).

The durability of a refurbished tire once can be equal to and even superior to a new tire. There are three types of tire retreads: Retreading, retreading and re-molding. Retreading is the 
DOI: 10.14807/ijmp.v11i7.1087

process of retreading by replacing the tire tread, while retreading is replacing the tread and shoulders. While in remoulding the process is a little more complex because 3 parts are replaced, the tread, shoulders and the entire surface of the flanks.

\subsection{Costs}

Cost management is one of the essential factors for making decisions within the company, should have a good structure so that the values are clear, to the point of helping the analysis of losses, gains, expenses, profits and the like. According to (BACIC, 2011), it is not only an accounting need for cost management, since a company that does not know its costs, it does not make correct decisions.

Decisions about the price of products, discount values, exclusion of products that are causing losses, outsourcing of activities, purchase of new equipment, modifications in the manufacturing process, among others, are made without there being any necessary information.

According to Merlone (2012), managing costs is:

[...] one of the most important activities that an entrepreneur can resort to to enhance the revenue of his business, because in a capitalist market where the major objective is the generation of income and profit, avoiding unnecessary expenses helps a lot in the budget for having good representation in the final result (p.01).

The company that focuses on better understanding its costs, it is a step forward in improving results, this happens due to the visualization of weaknesses and make corrections when the company is strong (CAMPOS, 2012).

The cost management requires objective and correct information that help in the decision-making process of the company and its maintenance in the scenario that operates, thus, it is up to the system to collect the data and turn them into information. According to (OLIVEIRA, 2016), every company needs cost analysis and control, whether small medium or large companies, the survival of these companies in the market, comes from the profit handled by the values and volumes generated from transactions, as well as seek to meet the needs of their customers, which is essential for their permanence in the market.

Companies should be aware that, in order to continue to provide profits to their owners, which is a basic condition for them, the profit cannot be obtained through intuitive means, it should be studied exclusively the consumer, understanding and working on the needs (OLIVEIRA, 2016).

\subsection{Rework}


DOI: 10.14807/ijmp.v11i7.1087

Throughout the production process, there is the possibility of rework resulting from failures, errors, omissions, damage or requests for change. It is common to have rework at some stage, but this should be reduced to the maximum, so that it does not have direct impacts on the final costs of the product. According to Matos (2014), the rework brings with it, consequences, which are not beneficial to anyone, for this it should be treated quickly and properly, without loss of productivity, interference in quality, low productivity, for example.

According to PMI (Project Management Institute) (2013), the rework is the action of doing with what was imperfect or out of the established standard, it complies with the requirements or specifications. In addition to causing the employee a professional demotivation, by redoing everything again, the work can generate serious consequences such as the loss of time, in certain stages where there is need for corrections. The loss of money on account of reprocessing is a serious factor within the company, when there is an action to be remade, the amount invested may have been redirected from other factors of manufacturing, thus increasing the final cost of the product.

In addition, Matos (2014) mentions that the lack of communication is one of the attributes that contributes to the rework, another factor that increases the occurrence of rework is the lack of review by managers, who need to be always aware of the whole process, focusing on the important steps.

In complex environments, such as the large industry sector, in which there is a production chain with several sectors, various interdependent activities, there are frequent errors, omissions and misunderstandings, resulting in undesirable outputs, in which they should be reassessed (HEGAZY et al., 2011).

\subsection{Quality tool}

Quality is a term often used in productive environments, but the meaning of the word is understood in various ways by people and it would be difficult to reach an agreement for the definition (PALADINI, 2012). Toledo et. al. (2014) reports that David Garvin classifies them into 4 "quality eras": Inspection, statistical quality control, quality assurance and quality management.

According to (PALADINI, 2012), the tools of quality management can be understood as a simple structuring to be implemented or help in analyses in the production process with 
DOI: 10.14807/ijmp.v11i7.1087

the aim of generating improvements, showing the errors that affect a certain stage of production. Toledo et. al. (2014) points out the 7 quality tools:

- Flowchart: It is a diagram, where it expresses a certain process or workflow in a sequential way, in a simple and easy to understand way and are linked by arrows, in which they indicate the direction and the following sequence.

- Stratification: Its purpose is to separate the data collected into different groups, such as location, type, time, date, step, etc. A tool that allows analyzing in which group without finding the problem.

- Pareto Diagram: It is a bar graph, built by data collection, where the individual selects several factors, where he will put the problems in descending order, in order to prioritize problems of greater impact.

- Histogram: Statistical model for data organization, with the function of identifying the frequency in which a certain value or values of a sample occur, this will allow analyzing the efficiency of the process.

- Cause and effect diagram: This is a diagram used to relate a process outcome (effect) and factors (causes), i.e. in which they take all aspects that may have led to the problem occurring.

- Dispersion Diagram: A graphical tool that demonstrates the relationship between two variables and quantifies the intensity between them, verifying if there is a cause and effect relationship.

Paladini et. al. (2012) states that, the tools mentioned above, have as their sole objective, to generate quality, the way will depend on each tool.

\subsection{Case Study}

Yin (2010) defines that the case study is a method of practical research that can be applied in various situations, and that can aim to explore, describe and explain the situation or deeply understand an individual or group phenomenon studied. The author also states that the study should be able to justify the theme in question, with the intuition to clarify, starting from an initiated problem, issues such as: "why" and "how" are clear the objectives.

The researcher should be able to find means of research that may be relevant, i.e., use various research methods, making a survey of case study Yin (2010). In addition, with a survey 
DOI: 10.14807/ijmp.v11i7.1087

of data of strong evidence, has the possibility of obtaining different sources of evidence, in which it will have a basis of historical and behavioral aspects.

It is still important to mention, a doubt that perhaps torments the researchers, a confusion between the research methods: quantitative and qualitative and the paradigms. The "qualitative" method is not synonymous with an "interpretive" philosophical position. The research may or may not be interpretative, depending on the assumptions affirmed by the researcher during his investigation. Qualitative research can be critical, interpretative or positivist, with this can be defined a qualitative research method, such as case study and action research (YIN, 2010).

\subsection{Monte Carlo}

The Monte Carlo method (MMC) was developed around 1946 by Polish mathematician Stanislaw Ulam during the Second World War in order to solve mathematical problems that were not feasible through analytical treatment. During the game patience, Ulam decided to analyze the possible probabilities of such a move happening, however, realized a great deal of time to conduct such an experiment. Faced with this formula, there was a more practical alternative, in which he would make numerous moves, and thus count the times that each result happened, to thus verify the variations that a certain move would be able to make (BREITMAN, 2012).

The Monte Carlo method is a probabilistic approach that allows considering uncertainty when calculating the expected value, i.e., analyze what can occur and what the probability that such a situation occurs. Using probabilistic distributions for the input parameters involved in the analysis, it is possible to recover the resulting value through a probability distribution. Each iteration performed in the MMC consists of presenting random values through the distribution of inputs made and calculating the corresponding result (PILLOT; SIQUEIRA; DIAS, 2018).

Fermino et al (2012) discusses Monte Carlo:

\footnotetext{
"The Monte Carlo method (MMC) can be described as a statistical method, in which a sequence of random numbers is used to perform a simulation, such as the behavior of the economy, which is based not only on an exact value, but with probability and randomness. This application of the MMC will make it easier for investors to make decisions based on statistical and random data. With the objective of making a tool for analyzing these data, which can help in the financial area, more precisely in risk analysis such as IRR (Internal Rate of Return) and NPV (Net Present Value)..”
}

According to Paula (2014), Monte Carlo's method is widely used to analyze a sequence of random numbers through simulations, in order to highlight what may occur in a given sample 
DOI: 10.14807/ijmp.v11i7.1087

and the probability of such a situation occurring. The method is referred to as a stochastic simulation, simple, and can be implemented, for example, in the evaluation of costs within a company.

\section{METHODOLOGY}

In this research, a case study was used in a tire retreading company. The present study was conducted through an exploratory research, in a period from Feb/2019 to March/2019, under quantitative methods, in which it obtained data collection and observation of the process of the tires themselves.

The histogram and the scatterplot were not used because the 5 tools already satisfy the need for the research in question. In the application of the quality tools, we reported each one of them and its role within the company studied, with the purpose of identifying errors, failures in the process to reduce costs and rework.

- Flowchart: The company's flowchart showed us clarity throughout the process, identifying previous and subsequent steps in order to help us systematically visualize an interdependent process..

- Check sheet: The check sheet was one of the important tools in which we found the main problems arising in the process. By obtaining data produced in a certain period, we had the amount of problems arising in each process that were the failures.

- Stratification: With the stratification, we separated the stages of the process, and limited it to a certain period of time, in which it was done between January and December 2018, in order to specify where there were greater occurrences of failures.

- Pareto Diagram: In the Pareto diagram, we can show in a percentage way, ordered and being from the highest to the lowest frequency, through bar graphs, which were the most serious problems that had been occurring to be reduced or even eliminated in the process.

Cause and effect diagram: The main problems were raised during the process evaluation together with the employees and managers, so that we could analyze them. The diagram takes into account the aspects that may have led to the occurrence of the problem. This tool helps to broaden the view of the possible causes of a problem, seeing it in a more concrete way. 
DOI: 10.14807/ijmp.v11i7.1087

After data collection, the quality tools were applied, analyzing the process, from the receipt of the tires to the delivery to the final customer, evaluating each step in order to diagnose failures in the process, it was possible to relate mainly the failures with the factors: labor, machines and method, thus being proposed actions for improvements in the production process of the respective company.

\section{DATA COLLECTION}

\subsection{The Company}

The tire retreading company is located in the South-Fluminense region of the state of Rio de Janeiro, was founded in 1999, currently has 20 employees in the process, 2 of these are for rework, The company is the first and has no branches, it has operations throughout the state of Rio de Janeiro, with a higher profitability in the South Fluminense region, it also has a partnership with a major supplier, which has advanced technology in the process of retreading cargo tires. In 2018, the company produced 5,400 tires per year, $66 \%$ of which were car tires and $33 \%$ load tires.

\subsection{Study of Costs and Rework in the Company}

In relation to the rework in the company, the tires not approved in the final inspection, but that still have conditions of application, are redirected to production, and should rather be noted in the order of services the problems presented and the causes that motivated these problems.

Depending on the problem presented, the tire can be scraped again for the application of a new tread, or just undergo a localized repair. Regardless of the defect presented, the tire will be vulcanized again.

Another point analysed was the costs that the company had in relation to the tyre retreading process, as shown in table 1 :

Table 1: Average quantity of each product in tire retread

\begin{tabular}{ccc}
\hline Feedstock & Car Tires & Cargo Tires \\
\hline Glue & $100 \mathrm{~mL}$ & $300 \mathrm{~mL}$ \\
Tread & $2,5 \mathrm{~kg}$ & $14 \mathrm{~kg}$ \\
Joint & $1 / 2 \mathrm{~m}$ & $3 \mathrm{~m}$ \\
Ink & $0.50 \mathrm{~mL}$ & $100 \mathrm{~mL}$ \\
\hline \multicolumn{3}{c}{ Source: prepared by the authors $(2019)$}
\end{tabular}

According to table 1, it shows us the values of each material and the quantity of each product used, approximately, in each type of retreaded tire. 
DOI: 10.14807/ijmp.v11i7.1087

Table 2: Average cost of each product in tire retread

\begin{tabular}{ccc}
\hline Feedstock & Car Tires & Cargo Tires \\
\hline Glue & $\mathrm{R} \$ 2.10$ & $\mathrm{R} \$ 3.60$ \\
Tread & $\mathrm{R} \$ 39.00$ & $\mathrm{R} \$ 240.00$ \\
Joint & $\mathrm{R} \$ 4.00$ & $\mathrm{R} \$ 15.00$ \\
Ink & $\mathrm{R} \$ 0.40$ & $\mathrm{R} \$ 0.70$ \\
Total & $\mathrm{R} \$ 45.50$ & $\mathrm{R} \$ 259.30$ \\
\hline
\end{tabular}

Source: prepared by the authors (2019).

According to table 2, the quantity of each tire was analyzed, and their percentage in relation to the total produced, in which 5,400 tires were already finished.

Table 3: Production in\% by tire type / year

\begin{tabular}{ccc}
\hline Tire Type & Quantity & Percentual \\
\hline Car Tires & 3,564 & $66 \%$ \\
Cargo Tires & 1,836 & $33 \%$ \\
\hline \multicolumn{2}{c}{ Source: prepared by the authors (2019) }
\end{tabular}

Taking these values, according to table 3, together with the cost of each type of retreaded tire produced, we reached a total annual cost of $\mathrm{R} \$ 639,601.80$ in the year 2018. It is also worth mentioning that the operating cost of the employees was approximately $\mathrm{R} \$$ 396,000.00 in the period 2018.

\subsection{Quality Tools Study at the Company}

With the understanding of the company's process it was possible to develop and relate its activities. The company has a structured and objective flowchart in the process, being similar to a process of any other tire retreader, as we can analyze in figure 3.

\subsection{Monte Carlo Method Study in the Company}

According to table 4, we attribute parameters of maximum and minimum values referring to the most probable quantities of items that we found in the retreading process, these values are between $20 \%$, because there may be a variation of items in use and scrap within the process.

Table 4: Average quantity of each product in automobile tire retread

\begin{tabular}{cccc}
\hline Feedstock & Minimum & Maximum & More Probable \\
\hline Glue & $80 \mathrm{~mL}$ & $110 \mathrm{~mL}$ & $100 \mathrm{~mL}$ \\
Tread & $2.3 \mathrm{~kg}$ & $2.8 \mathrm{~kg}$ & $2.5 \mathrm{~kg}$ \\
Joint & $0.4 \mathrm{~m}$ & $0.7 \mathrm{~m}$ & $1 / 2 \mathrm{~m}$ \\
Ink & $0.4 \mathrm{~mL}$ & $0.65 \mathrm{~mL}$ & $0.50 \mathrm{ml}$ \\
\hline
\end{tabular}

Source: prepared by the authors (2019)

Table 5 shows us the same design as table 4, informing the parameters of the quantities of minimum and maximum products and most likely under the process, but these are according to the use within the retreading of the load tires. 
DOI: 10.14807/ijmp.v11i7.1087

Table 5: Average quantity of each product in the load tires retread

\begin{tabular}{cccc}
\hline Feedstock & Minimum & Maximum & More Probable \\
\hline Glue & $250 \mathrm{~mL}$ & $350 \mathrm{~mL}$ & $300 \mathrm{~mL}$ \\
Tread & $13 \mathrm{~kg}$ & $16 \mathrm{~kg}$ & $14 \mathrm{~kg}$ \\
Joint & $2.7 \mathrm{~m}$ & $3.3 \mathrm{~m}$ & $3 \mathrm{~m}$ \\
Ink & $90 \mathrm{~mL}$ & $120 \mathrm{~mL}$ & $100 \mathrm{~mL}$ \\
\hline
\end{tabular}

Source: prepared by the authors (2019)

According to table 6, there are the costs in which each product was used in car tires and with the possibility of scrap during the process, but with the parameters of minimum and maximum values around $20 \%$, due to the variation in which can occur between a supplier or high/low that such supplier can establish in the product and also the probable that this cost is.

Table 6: Unit price of car tire raw material

\begin{tabular}{cccccc}
\hline Feedstock & \multicolumn{2}{c}{ Minimum } & \multicolumn{2}{c}{ Maximum } & Mais Provável \\
\hline Glue & $\mathrm{R} \$$ & 1.80 & $\mathrm{R} \$$ & 2.50 & $\mathrm{R} \$ 2.10$ \\
Tread & $\mathrm{R} \$$ & 37.50 & $\mathrm{R} \$$ & 42.00 & $\mathrm{R} \$ 39.00$ \\
Joint & $\mathrm{R} \$$ & 3.30 & $\mathrm{R} \$$ & 4.50 & $\mathrm{R} \$ 4.00$ \\
Ink & $\mathrm{R} \$$ & 0.30 & $\mathrm{R} \$$ & 0.50 & $\mathrm{R} \$ 0.40$ \\
TOTAL & $\mathrm{R} \$$ & 42.90 & $\mathrm{R} \$$ & 49.50 & $\mathrm{R} \$ 45.50$ \\
\hline \multicolumn{5}{c}{ Source: prepared by the authors (2019) }
\end{tabular}

In relation to table 7, it is possible to analyze the costs in the reform of cargo tires, having also the parameters of maximum, minimum and most probable values, showing the highest cost of the process is the tread that is the main element to be reformed.

Table 7: Cargo Tire Raw Material Unit Price

\begin{tabular}{|c|c|c|c|c|c|}
\hline Feedstock & \multicolumn{2}{|c|}{ Minimum } & \multicolumn{2}{|c|}{ Maximum } & More Probable \\
\hline Glue & $\mathrm{R} \$$ & 3.00 & $\mathrm{R} \$$ & 4.00 & $\begin{array}{lll}\text { R } & 3.60\end{array}$ \\
\hline Tread & $\mathrm{R} \$$ & 225.00 & $\mathrm{R} \$$ & 250.00 & $\mathrm{R} \$ 240.00$ \\
\hline Joint & $\mathrm{R} \$$ & 14.00 & $\mathrm{R} \$$ & 16.50 & $\mathrm{R} \$ \quad 15.00$ \\
\hline Ink & $\mathrm{R} \$$ & 0.55 & $\mathrm{R} \$$ & 0.90 & $\mathrm{R} \$ \quad 0.70$ \\
\hline TOTAL & $\mathrm{R} \$$ & 242.55 & $\mathrm{R} \$$ & 271.40 & $\mathrm{R} \$ 259.30$ \\
\hline
\end{tabular}

Source: prepared by the authors (2019)

According to table 8, we can observe the total produced of automobile tires and load tires, having as possibility of variation in the process between $14 \%$ to $22 \%$, minimum and maximum, respectively, being the most probable to happen in the company analyzed, is 5,400 tires/year.

Table 8: Production by tire type / year

\begin{tabular}{cccc}
\hline Tire Type & Minimum & Maximum & More Probable \\
\hline Car Tires & 3,000 & 4,000 & 3,564 \\
Cargo Tires & 1,200 & 2,300 & 1,836 \\
TOTAL & 4,200 & 6,300 & 5,400 \\
\hline
\end{tabular}

Source: prepared by the authors (2019)

Table 9 shows us the variable of rework in each stage of production, it can be seen that within the 43 rework occurred in 2018, a variation of minimum and maximum between 25\% was established, in which we obtained a value of 29 and 54 rework, respectively. 
DOI: 10.14807/ijmp.v11i7.1087

Table 9: Average amount of rework by type

\begin{tabular}{lrrr}
\hline $\begin{array}{c}\text { Default Type } \\
\text { (Step) }\end{array}$ & Minimum & Maximum & More Probable \\
\hline Vulcanization & 11 & 18 & 15 \\
Collage & 8 & 13 & 11 \\
Scaring and repair & 7 & 12 & 10 \\
Initial Inspection & 3 & 9 & 6 \\
Scraping & 0 & 2 & 1 \\
Tread application & & & \\
Scrolling & 29 & 54 & 43 \\
TOTAL & & & \\
\hline \multicolumn{2}{c}{}
\end{tabular}

Figure 3 allows us to have a clear view of its stages, from the entry of the tyre to be retreaded to the delivery to logistics. It is worth mentioning that the entity seeks to strictly follow this flow so that it has a quality product and that errors do not occur during the process, softening the rework.

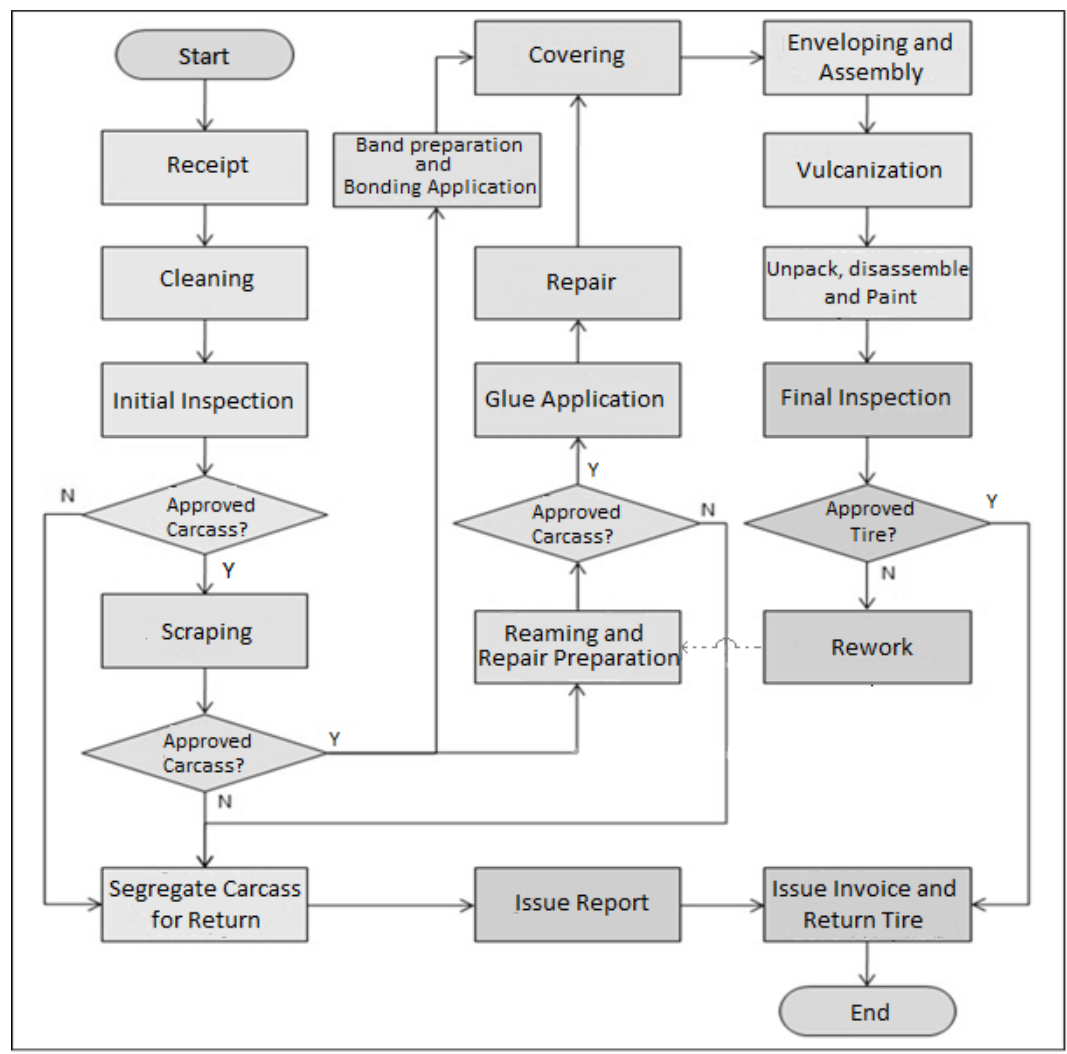

Figure 3: Process flowchart

Source: prepared by the authors (2019)

Another tool used in the company's process was the verification sheet, whose purpose facilitates the collection and organization of data for later analysis, the same may have many different forms, since for each situation may be necessary a certain type of arrangement to obtain the data. 
DOI: 10.14807/ijmp.v11i7.1087

A checklist is a format used to record the frequency of occurrence of certain qualityrelated characteristics of a product or service. From this, we have obtained the following data:

Table 10: List of defects arising from the process

\begin{tabular}{|c|c|c|c|}
\hline \multicolumn{2}{|c|}{ Manufacturing internship } & \multicolumn{2}{|c|}{ Period } \\
\hline \multicolumn{2}{|c|}{$\begin{array}{l}\text { Final inspection } \\
\end{array}$} & & 2018 \\
\hline Defect type (step) & Counting & Subtotal & $\%$ \\
\hline Vulcanization & lllllllllllllll & 15 & $34.90 \%$ \\
\hline Gluing & llllllllllll & 11 & $25.60 \%$ \\
\hline Escariating and Repairing & lllllllllll & 10 & $23.20 \%$ \\
\hline Initial Inspection & llllll & 6 & $14.00 \%$ \\
\hline Scraping & l & 1 & $2.30 \%$ \\
\hline Band preparation & Unobserved & & \\
\hline \multirow[t]{3}{*}{ Rolling } & Unobserved & & \\
\hline & Total & 43 & $100.00 \%$ \\
\hline & Total produced & 5,400 & \\
\hline
\end{tabular}

Source: prepared by the authors (2019)

Analyzing the numbers in table 10, we knew exactly where the main problems are and where they are affecting inside the company, with this we can make precise decisions. With this, we can verify that the vulcanization step contains the largest number of defects, followed by the gluing, with emphasis also on reaming/fixing.

\section{DATA ANALYSIS}

According to the data obtained according to table 10, we can identify the amount of tires with problems during the year 2018, and through the check sheet we can separate and quantify each problem within the process.

According to table 11, we found the respective values for each type of tire produced, the failures in each type of tire and also quantify the costs regarding the rework in which there was within the studied period.

Table 11: Total costs related to rework in the process

\begin{tabular}{cccc}
\hline & Automobiles & Cargo & Total \\
\hline Quantity & 29 & 14 & 43 \\
Total by type & $\mathrm{R} \$ 1,319.50$ & $\mathrm{R} \$ 3,630.20$ & $\mathrm{R} \$ 4,949.70$ \\
\hline
\end{tabular}

Source: prepared by the authors (2019)

With this, we can observe that under the total of 43 problems during the tire retreading process, the sum of car tire failures and loads in which there was rework in which the total cost was $\mathrm{R} \$ 4,949.70$.

Using the Monte Carlo Method, we conducted a simulation with 5,000 interactions under analysis of the parameters performed on the costs of car tires and loads produced. 
DOI: 10.14807/ijmp.v11i7.1087

According to table 12 , we can conclude that the average NPV is $\mathrm{R} \$ 4,733.62$, having as standard deviation a value of $\mathrm{R} \$ 415.78$, or $9 \%$ of coefficient of variation. In analyzing the simulations, it can be concluded that the probability of total cost and rework is higher than $\mathrm{R} \$ 4,000.00$ is $96.12 \%$.

Table 12: Statistics of VPL total

\begin{tabular}{lc}
\hline Statistical measure & \\
\hline Minimum & $\mathrm{R} \$ 3,172.30$ \\
Maximum & $\mathrm{R} \$ 6,468.89$ \\
Expected value & $\mathrm{R} \$ 4,733.62$ \\
Average & $\mathrm{R} \$ 4,731.71$ \\
Standard deviation & $\mathrm{R} \$ 415.78$ \\
$\mathrm{CV}$ & 0.09 \\
\hline Probability Cost and Rework Total & \\
\hline Total & $\mathrm{R} \$ 4,000.00$ \\
$p($ Total $>)$ & $96.12 \%$ \\
\hline
\end{tabular}

Source: prepared by the authors (2019)

Figure 4 shows us a graph due to the 5,000 simulations performed by the Monte Carlo Method, a histogram representing the frequency that occurs in the set of NPV class can be concluded that the minimum value of $\mathrm{R} \$ 3,172.30$ has possibility of occurrence almost 0 . The median found was $\mathrm{R} \$ 4,731.71$, this value does not deviate from the middle class in which it obtained a value of $\mathrm{R} \$ 4,733.62$, therefore not presenting a great difference between the mean and the median according to the simulation performed.

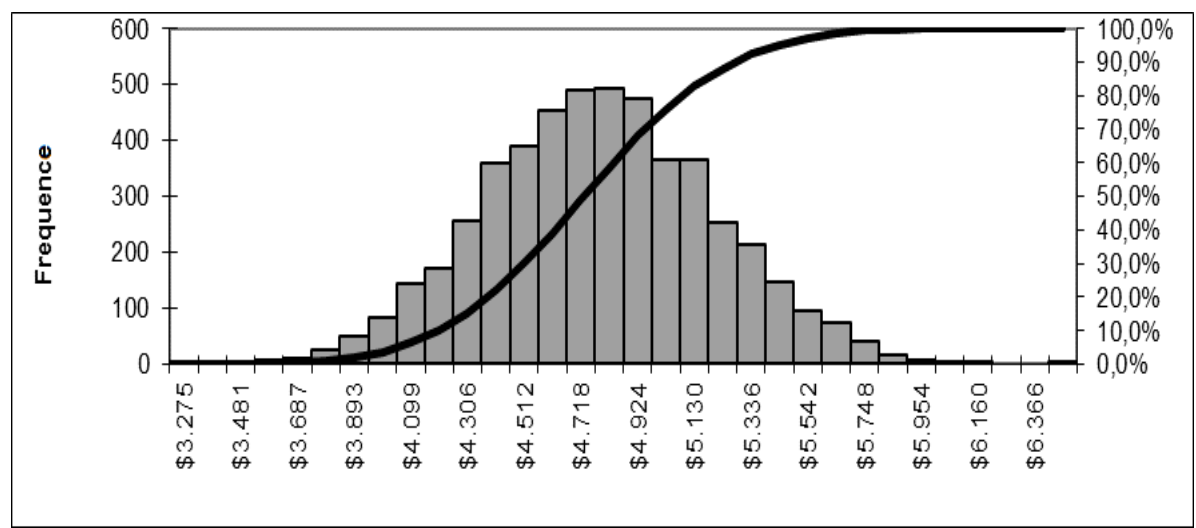

Figura 4: Frequency of VPL

Source: prepared by the authors (2019)

When analyzing figure 5, a graph showing the sequence of the mean and standard deviation of the NPV resulting from the 5,000 interactions can be observed, and small changes can be observed according to the interactions that occur. At the end of the simulation, one can conclude that the probability of a standard deviation being more precise becomes higher. 
DOI: $10.14807 /$ ijmp.v11i7.1087

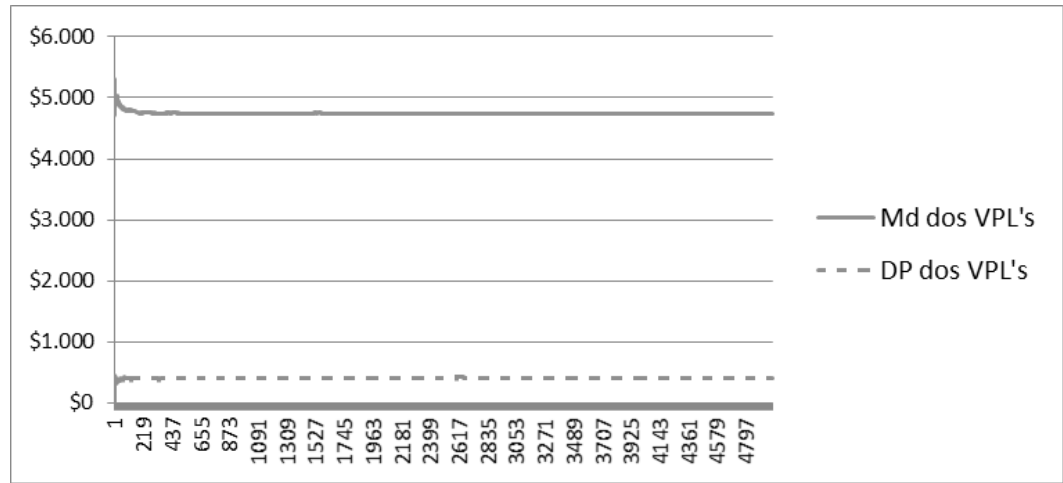

Figure 5: Mean and Standard Deviation of NPV Source: prepared by the authors (2019)

\section{CONCLUSION}

With the use of quality tools, it was possible to identify within the process of retreading, the failures that occurred, making a survey of costs generated by rework in these failures. We can identify that vulcanization, followed by gluing, scarring and initial inspection, were the steps that presented the highest numbers of frequency over the periods analyzed and should be prioritized.

It was also possible to carry out a survey of the cost of total production of load tires and cars produced in the company, through parameters of minimum and maximum values, we obtained before the 5000 interactions performed by the method of Monte Carlo a total cost related to rework with $96.12 \%$ probability is greater than $\mathrm{R} \$ 4000.00$, and the NPV was $\mathrm{R} \$ 4,733.62$ and the coefficient of variance in $9 \%$, not missing the median whose value was $\mathrm{R} \$ 4,731.71$ as shown in table 12.

It is recommended a study regarding the costs within the company with the use of the Monte Carlo method or another indicator, which can be performed in the services provided, such as logistics, in order to improve decision making and consequently the future economic viability.

\section{REFERENCES}

BACIC, M. J.; MEGLIORINI, E.; OLIVEIRA, E. C. M.; YOMURA, N. (2011) Manual de técnicas e práticas de gestão estratégica de custos nas pequenas e médias empresas. Conselho Regional de Contabilidade do Estado de São Paulo.

BOMFIM, E. A.; PASSARELLI, J. (2011) Custos e formação de preços.7 ed.- São Paulo: IOB.

BREITMAN, K. K. (2012) Arcabouço para desenvolvimento de serviços baseados na Simulação de Monte Carlo na Cloud. Dissertação (Mestrado em Informática), PUC-Rio. 
CAMPOS, V. F. (2014) TQC: controle da qualidade total. Belo Horizonte: Fundação CristianoOttoni/UFMG.

CAMPOS, Y. G. (2012) A importância da gestão de custos. Disponível em: $<$ http://www.administradores.com.br/artigos/negocios/a-importancia-da-gestao-decustos/63090>, acessado em 06 de maio de 2019.

FERMINO, M.; DANTAS, F.; CÂNDIDO, J.; COSTA, A. E.; PAULA, G. A.; PAULA, G. L. S. (2012) Método Monte Carlo para Análise de Risco. Book of Proceedings. Algarve.

FONTOURA, F. B. B. (2013) Gestão de custos uma visão integradora e prática dos métodos de custeio. São Paulo Atlas.

HEGAZY, T.; SAID, M.; KASSAB, M. (2011) Incorporating rework into construction schedule analysis. Automation in Construction, v. 20, n. 8, p. 1051-1059.

MARRONE, P. V. (2015) Livro branco da indústria de pneus - uma política industrial para o setor. São Paulo. ANIP.

MATOS, G. G. (2014) Comunicação empresarial sem complicação. Barueri: Manole, $3^{\mathrm{a}}$ ed.

OLIVEIRA, D. V. C. (2016) Contabilidade de custos: um estudo de caso sobre o ponto de equilíbrio de uma empresa no ramo faccionista têxtil. Trabalho de Conclusão de Curso (Ciências Contábeis), Universidade Rio Grande do Norte.

OLIVEIRA, R. (2017) Reformador de pneus é essencial para o segmento de transporte no Brasil. Revista Pnews, ed. 100, São Paulo.

PALADINI, E. P.; BOUER, G.; FERREIRA, J. J. A.; CARVALHO, M. M.; MIGUEL, P. A. C.; SAMOHYL, R. W.; ROTONDARO, R. G. (2012) Perspectiva estratégica da qualidade. In: CARVALHO, M. M.; PALADINI, E. P. (Org.) Gestão da Qualidade: Teoria e Casos.2 ed. Rio de Janeiro: Elsevier.

PAUlA, R. R.; DIAS, M. S. (2014) Método de Monte Carlo e Aplicações. 2014, 11 fl. Trabalho de Conclusão de Curso - (Matemática) - Universidade Federal Fluminense (UFF), Volta Redonda, RJ.

PILLOT, B.; DE SIQUEIRA, S.; DIAS, J. B. (2018) Grid parity analysis of distributed PV generation using Monte Carlo approach: The Brazilian case. Renewable Energy, v. 127, p. 974-988.

Project Management Institute - PMI. (2013) PMBOK: project management book of knowledge (5. ed.). Pensilvânia.

SANTOS, J. J. (2011) Contabilidade e análise de custos: modelo contábil, Métodos de depreciação, ABC-Custeio Baseado em Atividades, Análise atualizada de encargos sociais sobre salários, custos de tributos sobre compras e vendas. $6^{a}$ ed.-São Paulo: Atlas.

TOLEDO, J. C.; BORRÁS, M. A. A.; MERGULHÃO, R. C.; MENDES, G. H. S. (2014) Qualidade: gestão e métodos. Rio de Janeiro: LTC.

VALERIE, L. S. (2011) Waste, p. 297-320.

VALERIE, L. S. (2019) Waste, 2 ed., p. 489-515.

YIN, R. K. (2010) Estudo de caso: planejamento e métodos.4 ed.- Porto Alegre: Bookman. 
DOI: 10.14807/ijmp.v11i7.1087

ZANATTA, J. M.; FEDERAL, U.; MARIA, D. S. (2017)Análise de custos e preço de venda em uma distribuidora de produtos alimentícios. Revista Observatorio de la Economía Latinoamericana, Brasil. 